\title{
TAKLIM VIRTUAL MUSLIMAH PADA MASA PANDEMI COVID-19 DI WILAYAH PROVINSI BANGKA BELITUNG
}

\section{MUSLIMAH VIRTUAL TAKLIM DURING THE COVID-19 PANDEMIC IN BANGKA BELITUNG PROVINCE}

\author{
Hijrayanti Sari \\ Sekolah Tinggi Ilmu Islam dan Bahasa Arab (STIBA) Makassar \\ Email: hijrayanti@stiba.ac.id

\section{Amirullah} \\ Sekolah Tinggi Ilmu Islam dan Bahasa Arab (STIBA) Makassar \\ Email: amirullah14@stiba.ac.id

\section{Aswar} \\ Sekolah Tinggi Ilmu Islam dan Bahasa Arab (STIBA) Makassar \\ Email: aswar@stiba.ac.id
}

\begin{tabular}{ll}
\hline Keywords: & \multicolumn{1}{c}{ ABSTRACT } \\
\cline { 2 - 3 } Muslimah, Bangka Belitung & The Covid-19 pandemic presents its own challenges for the \\
implementation of education, research, and community service. \\
Various adaptations are made so that academic activities can \\
continue to run well, not least the implementation of KKN STIBA \\
Makassar in Bangka Belitung Region. Bangka Belitung Island \\
Province is a province in Indonesia consisting of two main islands \\
namely Bangka Island and Belitung Island as well as hundreds of \\
small islands. The purpose of the implementation of virtual \\
community service is intended so that the condition of pandemic \\
covid-19 is not the reason for the unfulperforming of various \\
muslimah education and coaching activities by students of KKN \\
STIBA Makassar in Bangka Belitung region. The various virtual \\
activities carried out for Muslims are: 1) Virtual weekly Taklim \\
Muslimah; 2) Construction of DIROSA; 3) Tahsin and Tahfiz \\
Online; 4) Virtual Arabic Teaching; 5) Learn Islam Intensively \\
Online; and 6) Pre-Ramadan Webinar. Although in the \\
implementation there are obstacles, such as the condition of the \\
network both participants and committees are less supportive, but \\
the obstacles do not reduce the spirit of da'wah KKN IV STIBA \\
Makassar students in Bangka Belitung Region, to be able to produce \\
twentyactive mentors whofollow various virtual coaching programs \\
during the kkn period is implemented.
\end{tabular}

Hijrayanti Sari, M. Amirullah, Aswar. Pengajian Virtual Muslimah... 
Website: https://journal.stiba.ac.id ISSN: 2723-6013 (Online)

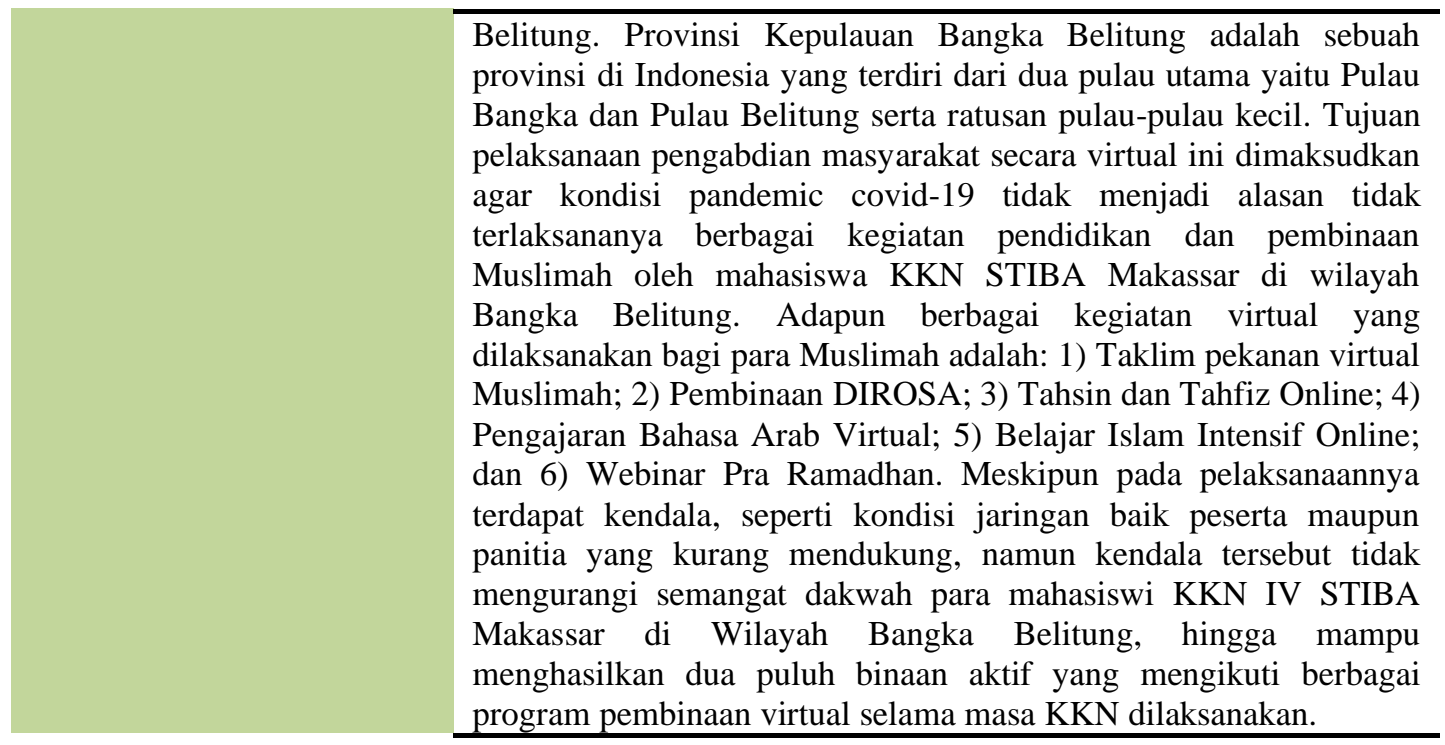

Diterima: 28 April 2021; Direvisi: 15 Mei 2021; Disetujui: 30 Mei 2021; Tersedia online: 18 Juni 2021

How to cite: Hijrayanti Sari, M. Amirullah, Aswar. "Taklim Virtual Muslimah pada Masa Pandemi Covid-19 di Wilayah Provinsi Bangka Belitung", WAHATUL MUJTAMA': Jurnal Pengabdian Masyarakat Vol.2, No.1 (Juni 18, 2021): 102-115. doi: https://doi.org/10.36701/wahatul.v2i1.350

\section{PENDAHULUAN}

Provinsi Kepulauan Bangka Belitung (disingkat Babel) adalah sebuah provinsi di Indonesia yang terdiri dari dua pulau utama yaitu Pulau Bangka dan Pulau Belitung serta ratusan pulau-pulau kecil, total pulau yang telah bernama berjumlah 470 buah dan yang berpenghuni hanya 50 pulau. Bangka Belitung terletak di bagian timur Pulau Sumatra, dekat dengan Provinsi Sumatra Selatan. Bangka Belitung dikenal sebagai daerah penghasil timah, memiliki pantai yang indah dan kerukunan antar etnis dengan Ibu kota provinsi adalah Kota Pangkalpinang.

Provinsi Kepulauan Bangka Belitung sebelumnya adalah bagian dari Sumatra Selatan, namun menjadi provinsi sendiri bersama Banten dan Gorontalo pada tahun 2000. Provinsi Kepulauan Bangka Belitung didirikan berdasarkan Undang-Undang Nomor 27 Tahun 2000 Tentang Pembentukan Provinsi Kepulauan Bangka Belitung tanggal 21 November 2000 yang terdiri dari Kabupaten Bangka, Kabupaten Belitung dan Kota Pangkalpinang. Pada tahun 2003 berdasarkan Undang-Undang Nomor 5 Tahun 2003 tanggal 23 Januari 2003 dilakukan pemekaran wilayah dengan penambahan 4 kabupaten yaitu Bangka Barat, Bangka Tengah, Bangka Selatan dan Belitung Timur.

Provinsi Kepulauan Bangka Belitung secara geografis terletak pada $104^{\circ} 50$ sampai $109^{\circ} 30$ Bujur Timur dan $0^{\circ} 50$ sampai $4^{\circ} 10$ Lintang Selatan, dengan batas

Hijrayanti Sari, M. Amirullah, Aswar. Pengajian Virtual Muslimah... 
wilayahnya di sebelah Barat berbatasan dengan Selat Bangka, sebelah Timur dengan Selat Karimata, sebelah Utara dengan Laut Natuna dan sebelah Selatan dengan Laut Jawa. Wilayah Provinsi Kepulauan Bangka Belitung terbagi menjadi wilayah daratan dan wilayah laut dengan total luas wilayah mencapai 81.725,14 $\mathrm{Km}^{2}$. luas wilayah daratan kurang lebih $16.424,14 \mathrm{Km}^{2}(20 \%$ dari total luas wilayah), dan luas wilayah laut kurang lebih $65.301 \mathrm{Km}^{2}(80 \%)^{1}$.

Kepulauan Bangka Belitung terdiri dari sekitar 470 pulau dan yang berpenghuni hanya 50 pulau. Pulau-pulau tersebut antara lain: Pulau Bangka, Pulau Belitung, Pulau Lepar, Pulau Pongok, Pulau Nanas, Pulau Mendanau, Pulau Nanas, Pulau Selat Nasik, Pulau Gersik, Pulau Bakau, Pulau Aur, Pulau Kalangbau, Pulau Kelemar, Pulau Kuil, dan Pulau Lengkuas. Provinsi Kepulauan Bangka Belitung mempunyai batas wilayah sebelah utara dengan Laut Natuna; sebelah timur dengan Selat Karimata; sebelah selatan dengan Laut Jawa; dan sebelah barat dengan Selat Bangka.

Wilayah Provinsi Kepulauan Bangka Belitung yang beribukota di Kota Pangkalpinang terbagi dalam 6 kabupaten dan 1 kota, yaitu Kabupaten Bangka, Bangka Barat, Bangka Tengah, Bangka Selatan, Belitung, Belitung Timur dan Kota Pangkalpinang. Propinsi kepulauan Bangka Belitung merupakan salah satu propinsi di Indonesia yang memiliki beraneka ragam obyek wisata baik jenis, bentuk, maupun ciri keunikan tradisional daerah. Propinsi Kepulauan Bangka Belitung merupakan propinsi dengan bentuk geografis wilayah kepulauan, tentu saja wilayah perairan merupakan wilayah yang mendominasi dari keseluruhan luas wilayah propinsi ini. Dari $81.725 \mathrm{~km}^{2}$ luas wilayahnya, $65.301 \mathrm{~km}^{2}$ atau $79.90 \%$ adalah merupakan wilayah perairan, sedangkan sisanya adalah daratan yang terdiri dari pulau-pulau dengan jumlah 1.015 buah pulau.

Wilayah Provinsi Kepulauan Bangka Belitung dikenal luas sebagai daerah objek wisata karena laut dan pantainya. Padahal sebenarnya wilayah provinsi Bangka Belitung memiliki potensi lain yang dapat dikelola secara optimal, diantaranya adalah potensi hutan dan lingkungan. Bahkan potensi hutan dan lingkungan di Bangka Belitung dapat dimanfaatkan sebagai potensi wisata yang tidak kalah menarik jika dikemas dengan baik agar termanfaatkan menjadi daya tarik wisata. Pemanfaatan potensi hutan dan lingkungan dapat dijadikan sebuah objek wisata yang berbasis hijau dengan pemberdayaan masyarakatnya, misalnya dengan mengembangkan green tourisme ${ }^{2}$.

\footnotetext{
${ }^{1}$ Soyusiawaty, Dewi, Rusydi Umar, and Rochmat Mantofani. "Sistem Informasi Geografis Objek Wisata Propinsi Kepulauan Bangka Belitung Berbasis Web." Seminar Nasional Aplikasi Teknologi Informasi (SNATI). 2007.

${ }^{2}$ Wardhani, Rulyanti Susi, and Devi Valeriani. "Green Tourism dalam Pengembangan Pariwisata Bangka Belitung." Prosiding Seminar Nasional INDOCOMPAC. 2016.
}

Hijrayanti Sari, M. Amirullah, Aswar. Pengajian Virtual Muslimah... 
Selain daerah laut, pantai, dan potensi lingkungan alam yang cukup memadai, Provinsi Kepulauan Bangka Belitung memiliki komoditi unggulan bada beberapa sektor, yaitu sektor pertambangan, pertanian, perkebunan, perikanan, peternakan dan jasa. Untuk sektor pertambangan komoditi yang diunggulkan adalah timah. Sementara komoditi penunjang sektor pertambangan adalah kaolin. Sektor pertanian komoditi unggulannya adalah jagung, ubi jalar dan ubi kayu. Sektor perkebunan dengan komoditi kelapa sawit, kakao, kopi, kelapa, cengkeh, karet dan lada. Sektor perikanan komoditi yang diunggulkan berupa perikanan tangkap, sub sektor perikanan meliputi budidaya jaring apung, budidaya keramba, budidaya laut, budidaya tambak dan budidaya kolam. Untuk sektor jasa komoditi yang diunggulkan adalah bidang pariwisata terutama wisata pantai, wisata alam dan wisata adat dan budaya. Sedangkan sektor pertanian komoditi unggulannya adalah sapi, babi, kambing dan kerbau.

Sebagai penunjang kegiatan perekonomian, di Provinsi Bangka Belitung terdapat dua bandar udara, yaitu Bandara Depati Amir di Kota Pangkalpinang dan Bandara HAS Hanandjoeddin di Kabupaten Belitung. Untuk transportasi laut tersedia 10 (sepuluh) pelabuhan, antara lain Pelabuhan penyeberangan Muntok, Pelabuhan Khusus Timah dan CPO di Kabupaten Bangka Barat dan Pelabuhan Sadai di Kabupaten Bangka. Untuk industri tersedia 8 kawasan industri, yaitu Jelintik di Kabupaten Bangka, Suge di Kabupaten Belitung, Sadai, Koba, Muntok, Air Kelik dan Ketapang yang didukung juga oleh fasilitas listrik dan telekomunikasi. Secara umum potensi wilayah provinsi Bangka Belitung dapat dikelompokkan menjadi lima sektor, yaitu: (1) pertanian dan perkebunan; (2) kelautan dan perikanan; (3) pariwisata; (4) industri pengolahan; dan (5) pertambangan ${ }^{3}$.

\section{PEMBAHASAN}

Kasus pandemi yang melanda dunia saat ini memaksa manusia beraktivitas dengan cara dan gaya baru (kebiasaan baru). Kegiatan yang melibatkan banyak orang dan berkumpul pada suatu ruangan tertutup menjadi hal yang perlu untuk dihindari dan dibatasi. Jika tetap perlu dilaksanakan, maka dilakukan dengan memperhatikan protokoler kesehatan yang ketat sehingga virus tidak menyebar. Saat ini berbagai kegiatan seperti seminar, pendidikan, aktivitas sosial, maupun ekonomi banyak dialihkan ke sistem online. Anak-anak melakukan aktivitas belajar secara online, para pekerja dan pegawai menjadi sangat familiar dengan rapat-rapat atau pelatihan yang dilakukan melalui media meeting online, bahkan untuk

\footnotetext{
${ }^{3}$ Potensi Daerah Bangka Belitung. https://bakuda.babelprov.go.id/content/potensi-daerahbangka-belitung
}

Hijrayanti Sari, M. Amirullah, Aswar. Pengajian Virtual Muslimah... 
Website: https://journal.stiba.ac.id ISSN: 2723-6013 (Online)

memenuhi kebutuhan belanja sebagian besar dilakukan melalui pemesanan secara online.

Perilaku masyarakat telah berubah dengan menjaga jarak, mengurangi kontak, dan bekerja secara virtual. Termasuk berbagai kegiatan pendidikan di Perguruan Tinggi, tidak terkecuali di Sekolah Islam dan Bahasa Arab (STIBA) Makassar. STIBA Makassar sejak awal pandemik mematuhi arahan pemerintah dan pihak terkait agar dapat mencegah dan meminimalisir terjadinya penyebaran virus covid-19. Aktivitas bekerja para pegawai dan aktivitas belajar para mahasiswa disesuaikan dan diatur sedemikian rupa sesuai dengan protokoler kesehatan yang dianjurkan. tidak hanya kegiatan di dalam kampus, termasuk juga berbagai penyesuaian dilakukan untuk berbagai aktivitas penelitian dan pengabdian masyarakat, seperti KKN STIBA Makassar.

Berbagai kegiatan akademik dan pengabdian masyarakat disesuaikan dan diatur sedemikan rupa agar dapat tetap berjalan di tengah kondisi pandemi. Salah satu strategi yang dilakukan adalah mengarahkan kegiatan tersebut secara virtual serta terbatas jika dilaksanakan dalam suatu tempat untuk mencegah penyebaran virus. Hal ini yang kemudian dilakukan oleh para mahasiswa putri STIBA Makassar yang berasal dari provinsi Bangka Belitung. Provinsi Bangka Belitung menjadi salah satu daerah yang terdampak Covid-19, sehingga disarankan dalam berbagai pelaksanaan kegiatan dalam mode online. Kegiatan yang biasanya dilaksanan secara langsung dengan menghadirkan peserta dalam suatu tempat yang sama dialihkan menjadi online sebagaimana arahan dari pemerintah dan kementrian terkait. Oleh karena itu, berbagai program KKN diselenggarakan dalam format virtual. Meskipun dilaksanakan dalam kondisi pandemi dengan berbagai penyesuaian-penyesuaian, mahasiswa STIBA Makassar yang melaksanakan KKN diwajibkan untuk tetap membawa semangat dan nama baik STIBA Makassar dalam proses pengabdiannya di Masyarakat. Selain itu, untuk menjaga kualitas pelaksanaan KKN STIBA Makassar, Pelaksanaan KKN yang digelar di wilayah dan daerah masing-masing mahasiswa tetap berada di bawah pengawasan dan supervisi Dosen Pembimbing Lapangan.

Sekolah Tinggi Ilmu Islam dan Bahasa Arab (STIBA) Makassar merupakan institusi Perguruan Tinggi Agama Islam yang berkonsentrasi pada pengaderan dai dan ulama. Dengan demikian, lulusannya diharapkan dapat berkiprah secara profesional dan berdedikasi untuk umat. Dalam rangka hal tersebut, maka orientasi pelaksanaan KKN STIBA Makassar dikemas dalam rangka mempersiapkan para mahasiswa dan mahasiswi mengambil peran sebagai dai dan daiyah karena pada dasarnya setiap muslim dan muslimah pada dasarnya mempunyai kewajiban untuk ber-dakwah, menyuruh kepada yang ma'ruf dan mencegah dari perbuatan mungkar. Dengan kondisi pandemic saat ini, maka oerientasi dakwah yang biasa dilakukan 
secara langsung pada berbagai ruang dan tempat dialihkan menjadi kegiatan virtual. Perubahan zaman yang kompleks dan dinamis membawa perubahan dan konteks aktivitas dan kehidupan, salah satu teknologi yang banyak dimanfaatkan dan berbaur dalam aktivitas manusia saat ini adalah internet. Fungsi dari internet juga tidak lagi sekedar menjadi pelengkap, tapi menjadi kebutuhan harian, termasuk dalam berbagai aktivitas pendidikan dan dakwah sebagai konsekuensi perkembangan ilmu pengetahuan dan tehnologi dewasa ini $^{4}$.

Berdasarkan Program Kerja yang telah disusun ada beberapa program besar yang telah disusun yaitu: pembinaan DIROSA, tahsin, tahfiz, taklim pekanan muslimah, mengajar bahasa arab, dan belajar Islam intensif, dan webinar. Seluruh kegiatan tersebut dilaksanakan secara virtual mengingat kondisi pandemik Covid19 yang masih berlangsung. Masing-masing program kegiatan dideskripsikan sebagai berikut:

\section{Taklim Virtual Muslimah Pekanan}

Taklim Muslimah adalah salah satu program kerja yang dilakukan sekali setiap pekan yakni pada setiap hari kamis, dengan tema yang beragam dan juga pemateri yang berganti-ganti. Secara umum, taklim muslimah bertujuan untuk menambah wawasan keislaman ${ }^{5}$, fikih seputar muslimah ${ }^{6}$, dan tentunya berorientasi pada upaya meningkatkan iman dan takwa kaum muslimah ${ }^{7}$. Pada kegiatan ini, para pemateri adalah mahasiswi KKN IV STIBA Makassar yang diutus di daerah Bangka Belitung, dengan menggunakan sistem bergilir, semua mahasiswi mendapatkan kesempatan sekali untuk menjadi pemateri. Jumlah peserta yang hadir pada kegiatan ini bervariasi, terkadang tujuh sampai sepuluh orang.

${ }^{4}$ Arief, Ulfah Mediaty, Feddy Setio Pribadi, and Agus Suryanto. "In Salimah Internet untuk Kelompok Pengajian Persaudaraan Muslimah (Salimah) Sebagai Upaya Mensosialisasikan Dakwah Secara Online."

5 Syahriani, Eka, and Awal Rifai. "Upaya Meningkatkan Pemahaman Keagamaan Masyarakat melalui Program Pendidikan dan Sosial Keagamaan di Desa Alatengae Kabupaten Maros." WAHATUL MUJTAMA': Jurnal Pengabdian Masyarakat 1.2 (2020): 142-156.

${ }^{6}$ Lambajo, Sartini, and Akhmad Hanafi Dain Yunta. "Mewujudkan Masyarakat Qur'ani melalui Program KKN STIBA Makassar di Desa Kalabbirang Kabupaten Maros." WAHATUL MUJTAMA': Jurnal Pengabdian Masyarakat 1.2 (2020): 157-173.

${ }^{7}$ Putri, Sri Ujiana, and Aswar Aswar. "Implementasi Pendidikan Masyarakat Berbasis Masjid untuk Muslimah di Desa Mattoanging Kabupaten Maros." WAHATUL MUJTAMA': Jurnal Pengabdian Masyarakat 1.2 (2020): 129-141.

Hijrayanti Sari, M. Amirullah, Aswar. Pengajian Virtual Muslimah... 
Website: https://journal.stiba.ac.id ISSN: 2723-6013 (Online)

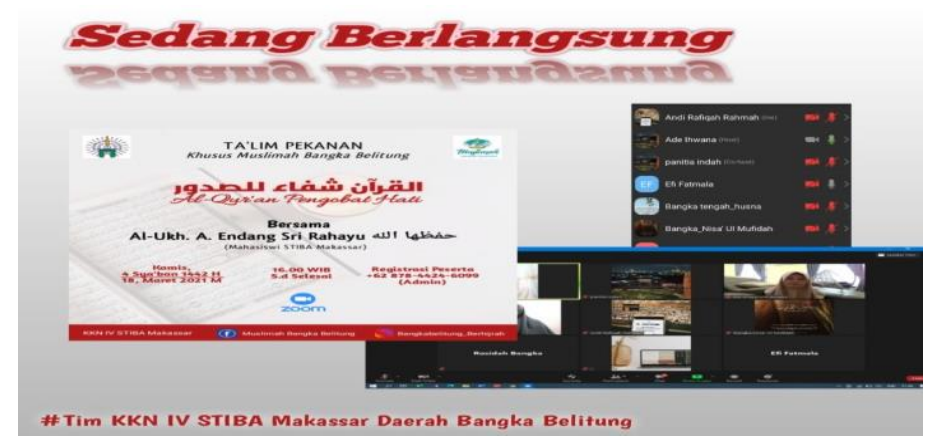

Gambar 1. Taklim Muslimah Pekanan

Adapun kendala pada kegiatan ini adalah jumlah peserta yang tidak pernah memenuhi target yang telah ditetapkan. Pada awal perencanaan program, tim KKN IV STIBA Makassar daerah Bangka Belitung menetapkan target peserta untuk kegiatan taklim pekanan adalah seratus orang, namun pada realisasinya, peserta yang hadir hanya berkisar antara tujuh sampai sepuluh orang. Kendala lainnya adalah masalah jaringan yang kurang kondusif untuk beberapa peserta sehingga tidak bisa turut hadir pada kegiatan taklim muslimah pekanan ini. Berbeda halnya jika taklim muslimah diselenggarakan secara offline, umumnya suasana taklim selalu ramai dengan candaan ibu-ibu muslimah dalam mendengarkan dan membenarkan materi taklim yang sesui dengan realita kehidupan sehari-hari ${ }^{8}$.

\section{Pembinaan DIROSA}

Pembinaan dirosa ini diselenggarakan untuk muslimah Bangka Belitung yang masih kurang kemampuan bacaan Al-Qur'an-nya. Secara utuh, Hendra dan Nurhidayah menyebutkan bahwa tujuan program pembinaan DIROSA antara lain: (1) Untuk meningkatkan semangat seseorang dalam mempelajari dan mengajarkan Al-Qur'an; (2) Memberikan tambahan wawasan dasar-dasar keislaman kepada peserta DIROSA; dan (3) Untuk memberikan pembelajaran baca Al-Qur'an kepada remaja dan orang dewasa agar dapat membaca sesuai ilmu dan kaidah tajwid ${ }^{9}$. Secara khusus, bertujuan dalam mengajarkan bagaimana mengucapkan huruf dengan benar sesuai makhārijul hurufnya ${ }^{10}$.

${ }^{8}$ Munawara, Munawara, and Iskandar Iskandar. "Implementasi Pengabdian Masyarakat melalui Pelaksanaan Dirasah Islamiyah di Desa Tukamasea Kabupaten Maros." WAHATUL MUJTAMA': Jurnal Pengabdian Masyarakat 1.2 (2020): 174-184.

${ }^{9}$ Wijaya, Hendra. "Pembelajaran Metode Dirosa di Desa Majannang Kabupaten Gowa." WAHATUL MUJTAMA': Jurnal Pengabdian Masyarakat 1.1 (2020): 67-74.

10 Putri, Sri Ujiana, and Aswar Aswar. "Implementasi Pendidikan Masyarakat Berbasis Masjid untuk Muslimah di Desa Mattoanging Kabupaten Maros." WAHATUL MUJTAMA': Jurnal Pengabdian Masyarakat 1.2 (2020): 129-141.

Hijrayanti Sari, M. Amirullah, Aswar. Pengajian Virtual Muslimah... 


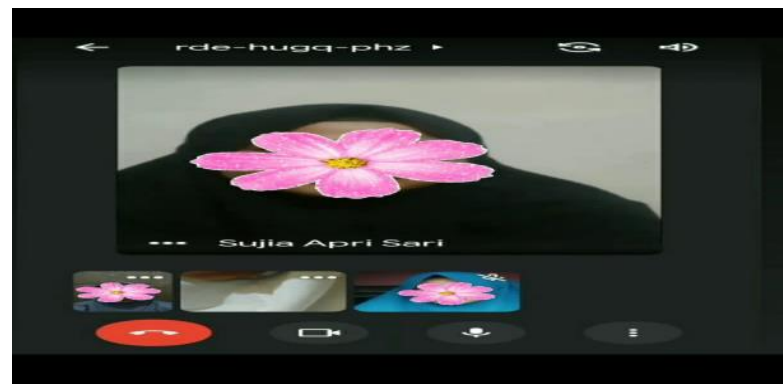

Gambar 2. Pembinaan DIROSA

Program ini dilaksanakan setiap hari senin, selasa, rabu, jumat, dan sabtu selama masa KKN. Adapun pembentukan halaqoh DIROSA dilakukan pada kegiatan taklim muslimah perdana oleh mahasiswi KKN IV STIBA Makassar daerah Bangka Belitung pada pekan pertama masa KKN. Dari kegiatan tersebut, tim KKN mampu membentuk lima halaqah, di mana masing-masing halaqah terdiri dari dua peserta. Selain itu, terdapat juga halaqah binaan yang sebelumnya dibina oleh Ustadz di Bangka Belitung dan dialihkan menjadi system virtual ke mahasiswi KKN STIBA Makassar, dalam halaqah tersebut terdapat 15 muslimah yang berasal dari Bangka Belitung. Dalam pelaksanaannya terdapat berbagai kendala, seperti jaringan peserta yang kurang kondusif dan sulitnya menyusuaikan waktu antara pengajar dan peserta.

\section{Tahsin dan Tahfiz Online}

Pelaksanaan tahsin diajarkan kepada muslimah Bangka Belitung yang sudah bisa membaca Al-Qur'an, namun bacaannya masih kurang dalam ketepatan makhraj, hukum tajwid, dan lain-lain. Halaqoh tahsin ini juga dibentuk saat taklim muslimah perdana. Adapun waktu pelaksanaannya, dilaksanakan setiap hari senin, selasa, rabu, jum'at, dan sabtu selama masa KKN. Kendala yang dihadapi dalam proses tahsin ini adalah masalah jaringan yang kurang kondusif. Namun, hal itu tidak menyulutkan semangat para peserta yang di ajar, karena mereka memliki semangat belajar yang tinggi. Sehingga program ini bisa dilaksanakan secara intensif.
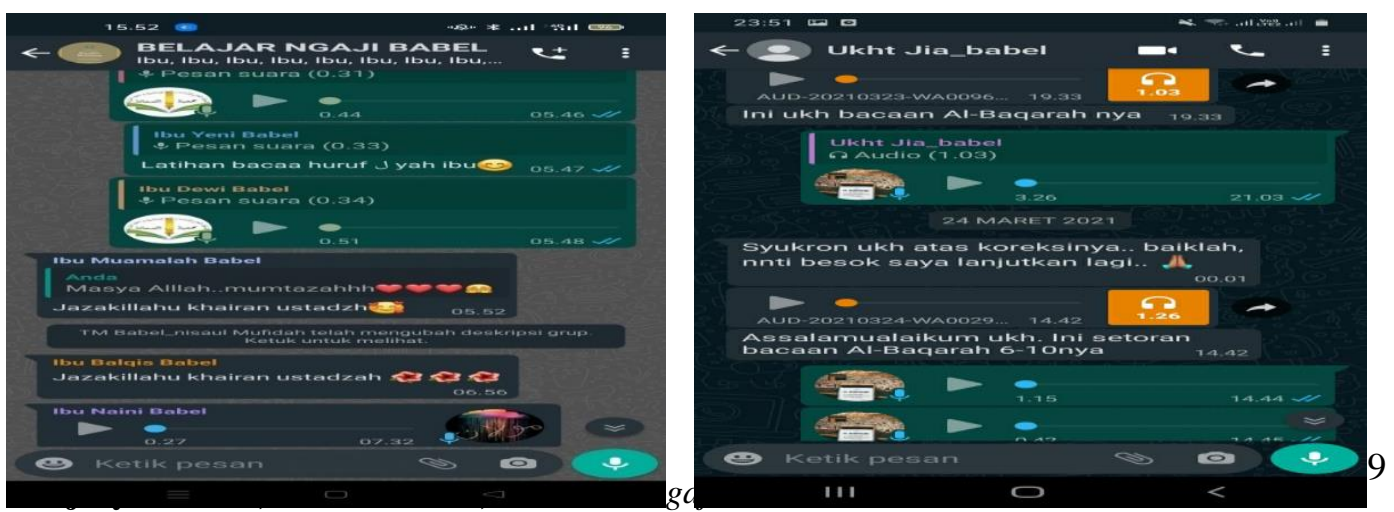
Website: https://journal.stiba.ac.id ISSN: 2723-6013 (Online)

\section{Gambar 3. Tahsin dan Tahfiz Online}

Adapun pelaksanaan tahfiz diajarkan kepada muslimah Bangka Belitung yang cara membacanya Al-Qur'an-nya sudah bagus. Program ini, merupakan rangkaian dari program tahsin yang diselenggarakan oleh tim KKN IV STIBA Makassar daerah Bangka Belitung. Senada dengannya, Rahmat dan Khaerul menyebutkan bahwa program tahfiz pada permulaannya bertujuan untuk memperbaiki bacaan, lalu kemudian memperbaiki hafalan yang keliru, dan pastinya berorientasi dalam menambah jumlah setoran hafalan seseorang ${ }^{11}$.

Adapun waktu pelaksanaannya, dilaksanakan setiap hari senin, selasa, rabu, jumat, dan sabtu selama masa KKN. Kendala yang dihadapi, karena kurangnya sosialisasi tentang keutamaan menghafal Al-Qur'an, maka hal tersebut berdampak pada kurangnya minat Muslimah Bangka Belitung untuk mengikuti program ini. Sehingga jumlah muslimah Bangka Belitung yang dibina hafalannya oleh tim $\mathrm{KKN}$, hanya berjumlah lima orang.

\section{Pengajaran Bahasa Arab Virtual}

Kegiatan mengajar bahasa arab dilakukan intensif sekali dalam sepekan. Namun, pembentukan kelas bahasa Arab baru bisa dilaksanakan pada pekan ke-dua masa KKN IV STIBA Makassar melalui penyebaran pamflet kelas bahasa Arab yang diselenggarakan oleh tim KKN IV STIBA Makassar daerah Bangka Belitung. Jumlah kelas yang terbentuk dari program tersebut adalah 5 kelas. Di mana masingmasing kelas dibina oleh satu orang mahasiswi KKN dengan jumlah peserta 3 orang. Adapun tujuan dari pengajaran bahasa Arab di antaranya yaitu (1) memperkenalkan dan menumbuhkan kecintaan pada bahasa Arab serta memberikan pengayaan dalam menghafalkan mufrodat (kosa kata) dan dasar-dasar kaidah berbahasa Arab ${ }^{12}$; dan memperbaiki makharijul huruf dalam penyebutan bahasa $\mathrm{Arab}^{13}$.

11 Tempo, Rachmat Bin Badani, and Khaerul Aqbar. "Ikhtiar Mahasiswa KKN STIBA Makassar dalam Pembentukan Akhlak Qur'ani Masyarakat Desa Balassuka Kabupaten Gowa." WAHATUL MUJTAMA': Jurnal Pengabdian Masyarakat 1.1 (2020): 90-115.

${ }^{12}$ Lambajo, Sartini, and Akhmad Hanafi Dain Yunta. "Mewujudkan Masyarakat Qur'ani melalui Program KKN STIBA Makassar di Desa Kalabbirang Kabupaten Maros." WAHATUL MUJTAMA': Jurnal Pengabdian Masyarakat 1.2 (2020): 157-173.

${ }^{13}$ Munawara, Munawara, and Iskandar Iskandar. "Implementasi Pengabdian Masyarakat melalui Pelaksanaan Dirasah Islamiyah di Desa Tukamasea Kabupaten Maros." WAHATUL MUJTAMA': Jurnal Pengabdian Masyarakat 1.2 (2020): 174-184.

Hijrayanti Sari, M. Amirullah, Aswar. Pengajian Virtual Muslimah... 


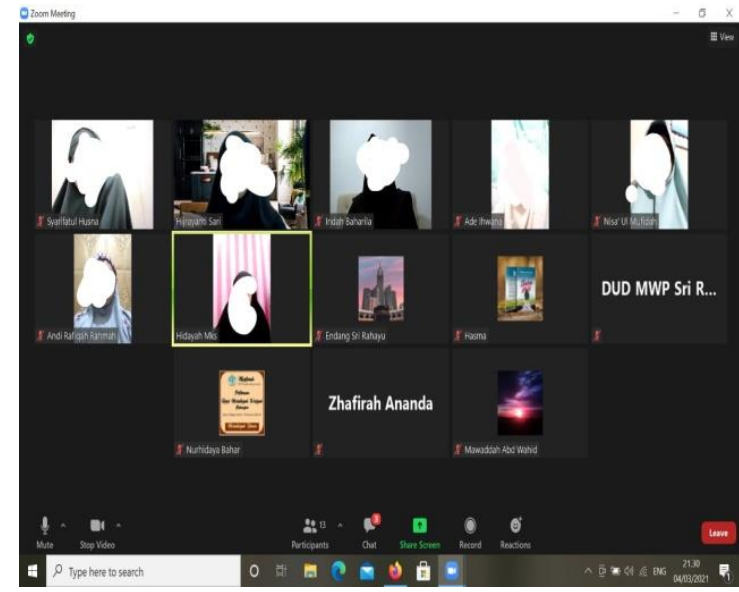

\section{Gambar 4. Pengajaran Bahasa Arab Virtual}

Kegiatan mengajar bahasa Arab yang dilakukan dengan cara mengajarkan dasar-dasar bahasa arab terlebih dahulu kepada muslimah Bangka Belitung dan menggunakan buku panduan pengajar bahasa Arab dari Departemen DIKLAT Keputrian DEMA STIBA Makassar. Adapun kendala dari kegiatan ini adalah kurangnya minat muslmah Bangka Belitung untuk belajar bahasa Arab.

\section{Belajar Islam Intensif Online}

Pelaksanaan Belajar Islam Intensif atau tarbiyah, diajarkan kepada muslimah Bangka Belitung yang memiliki minat untuk belajar ilmu Islam. Pembentukan halaqoh tarbiyah dilakukan pada taklim muslimah perdana dan pada setiap program besar tim KKN IV STIBA Makassar daerah Bangka Belitung sebagai bentuk follow up dari program-program tersebut. Halaqoh tarbiyah yang terbentuk ada lima halaqoh di mana masing-masing halaqoh terdapat tiga peserta dan peserta tersebut dibina langsung oleh mahasiswi KKN IV STIBA Makassar daerah Bangka Belitung. Sehubungan dengannya, kegiatan tarbiyah seyogianya dimulai dengan pembukaan majelis, kemudian tahsinul qiraah, dan setiap mutarabbiyah (murid muslimah) membaca Al-Qur'an secara bergiliran, lalu murabbiyah (guru muslimah) mengoreksi setiap bacaan yang salah dari mutarabbiyah-nya ${ }^{14}$.

${ }^{14}$ Lambajo, Sartini, and Akhmad Hanafi Dain Yunta. "Mewujudkan Masyarakat Qur'ani melalui Program KKN STIBA Makassar di Desa Kalabbirang Kabupaten Maros." WAHATUL MUJTAMA': Jurnal Pengabdian Masyarakat 1.2 (2020): 157-173.

Hijrayanti Sari, M. Amirullah, Aswar. Pengajian Virtual Muslimah... 


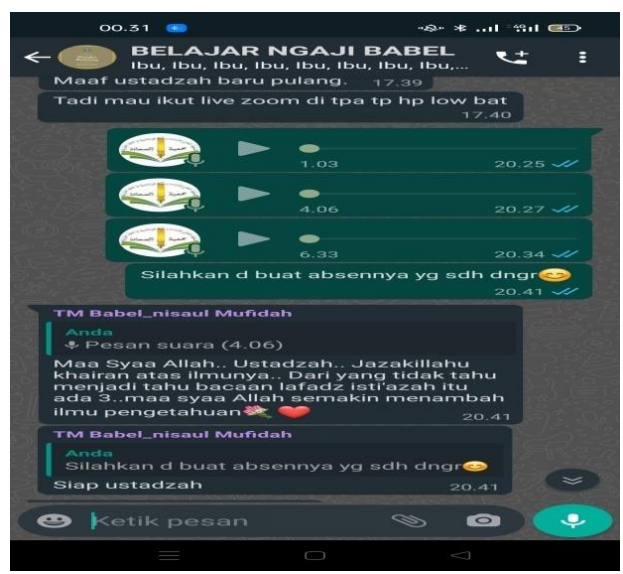

Gambar 5. Belajar Islam Intensif Online

Kendala yang dihadapi dalam kegiatan ini adalah jaringan yang kurang kondusif dan pada beberapa halaqah ada muslimah yang tidak memiliki aplikasi Zoom maupun Google Meet.

\section{Webinar Pra Ramadan}

Kegiatan ini dilaksanakan secara virtual dan dirangkaikan dengan bedah buku Ramadankan Hidupmu dan juga mengangkat tema yang sama dengan judul buku tersebut. Tujuan utamanya tidak lain agar para peserta dapat mempersiapkan mental dan ruhiyah-nya serta menambah wawasan keislamannya sebelum memasuki bulan suci Ramadan. Pada webinar ini, tim KKN IV STIBA Makassar daerah Bangka Belitung menghadirkan pemateri Ustadzah Arimda, Lc. Selain penulis buku Ramadankan Hidupmu, beliau juga merupakan Kepala Keputrian di Sekolah Tinggi Ilmu Islam dan Bahasa Arab (STIBA) Makassar.

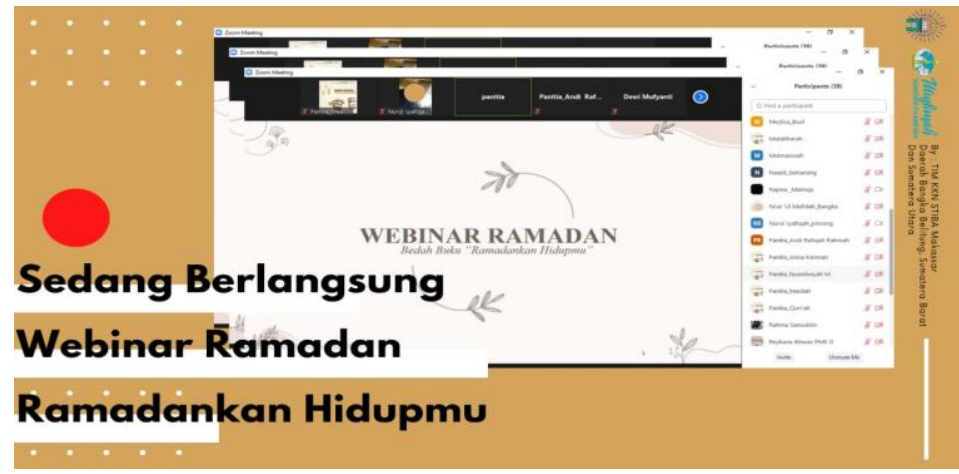

Gambar 6. Webinar Pra Ramadhan

Hijrayanti Sari, M. Amirullah, Aswar. Pengajian Virtual Muslimah... 
Website: https://journal.stiba.ac.id ISSN: 2723-6013 (Online)

Adapun kendala dari kegiatan ini adalah kurangnya jumlah peserta yang mendaftar. Sehingga pada H-5 kegiatan, tim KKN IV STIBA Makassar daerah Bangka Belitung mengajak tim KKN IV STIBA Makassar daerah utusan Sumatra Barat dan Sumatra Utara untuk turut berpartisipasi menjadi penyelenggara kegiatan webinar ini. Harapannya agar jumlah peserta bisa mencapai target yakni 65 orang, dimana masing-masing tim KKN, menghadirkan 20 dan 25 orang peserta. Sehingga kegiatan yang harusnya dilaksanakan pada hari ahad pekan terakhir masa KKN harus diundur pada hari kamis. Walhasil, kegiatan tersebut sukses dilaksanakan meskipun jumlah peserta hanya 40 orang.

\section{Hasil Kegiatan dan Keberlanjutan Program Kegiatan}

Berbagai macam program KKN yang telah diselenggarakan oleh tim KKN STIBA Makassar angkatan ke-IV khususnya untuk daerah Bangka Belitung, telah memberikan kesan yang baik terhadap muslimah Bangka Belitung. Hal ini dapat dilihat dari respon salah seorang muslimah Bangka Belitung yang dibina oleh Mahasiswi KKN IV STIBA Makassar. Beliau menuturkan bahwa:

\footnotetext{
"Kebanyakan ibu-ibu sangat membutuhkan wadah untuk mereka bisa belajar AlQur'an dan belajar Islam intensif karena secara umum masih banyak muslimah Bangka Belitung yang belum mengetahui cara membaca Al-Qur'an dengan baik dan benar."
}

Selain itu, pada survei yang kami lakukan melalui diskusi hangat dengan para muslimah Bangka Belitung, juga membuktikan adanya dampak perubahan yang signifikan. Mulai dari bacaan Al-Qur'an para muslimah Bangka Belitung, kosa-kata bahasa Arab, hingga pengetahuan Islam secara umum sudah mulai dikuasai oleh para muslimah di sana. Hal ini ditunjang oleh program pembentukan halaqah tahsin, DIROSA, bahasa Arab, ta'lim muslimah, pun juga tarbiyah yang dilaksanakan secara intensif oleh tim KKN IV STIBA Makassar yang diutus di Bangka Belitung. Pada akhir diskusi hangat tersebut, para muslimah menuturkan harapan mereka, bahwa kegiatan belajar mengajar antara mslimah Bangka Belitung bersama para mahasiswi KKN IV STIBA Makassar tetap bisa terus berjalan meskipun masa KKN-nya telah berakhir.

Sebagaimana harapan para muslimah Bangka Belitung yang telah dipaparkan di atas, maka program-program yang ditetapkan akan dilanjutkan oleh mahasiswi KKN IV STIBA Makassar khususnya di daerah Bangka Belitung setelah masa KKN ini selesai adalah program kelas tahsin, DIROSA, dan bahasa Arab virtual. Kegiatan-kegiatan tersebut bertujuan, untuk membina muslimah Bangka Belitung yang telah direkrut dalam kelompok belajar ini, agar dapat mengamalkan serta mengajarkan ilmu-ilmu tersebut kepada muslimah Bangka Belitung lainnya maupun masyarakat Bangka Belitung secara umum.

Hijrayanti Sari, M. Amirullah, Aswar. Pengajian Virtual Muslimah... 
Website: https://journal.stiba.ac.id ISSN: 2723-6013 (Online)

\section{KESIMPULAN}

Seluruh program kegiatan yang diagendakan oleh Mahasiswi KKN IV STIBA Makassar di wilayah Bangka Belitung, disambut baik oleh para muslimah di wilayah setempat. Meskipun pada pelaksanaannya terdapat berbagai kendala, seperti kondisi jaringan baik peserta maupun panitia yang kurang mendukung, dan kendala-kendala lainnya. Namun berbagai kendala tersebut tidak menyulutkan semangat pengabdian masyarakat para mahasiswi KKN IV STIBA Makassar di wilayah Bangka Belitung, sehingga mampu menghasilkan dua puluh binaan aktif selama masa KKN tersebut.

Berdasarkan hasil dari pelaksanaan, pengamatan, dan pengalaman, selama masa KKN di Provinsi Bangka Belitung, maka direkomendasikan untuk penempatan mahasiswa secara virtual yang harus mempertimbangkan kondisi jaringan mahasiswa, karena mengingat program-program KKN oleh tim KKN IV STIBA Makassar yang diutus virtual ke daerah-daerah tertentu, dilakukan secara online seluruhnya. Selain itu, mahasiswa yang diutus ke lokasi KKN perlu mengetahui kondisi penduduk dan masyarakat setempat di daerah utusan tersebut agar memudahkan tim KKN dalam pemetaan dan pelaksanaan berbagai program KKN.

\section{DAFTAR PUSTAKA}

Arief, Ulfah Mediaty, Feddy Setio Pribadi, and Agus Suryanto. "In Salimah Internet untuk Kelompok Pengajian Persaudaraan Muslimah (Salimah) Sebagai Upaya Mensosialisasikan Dakwah Secara Online."

Lambajo, Sartini, and Akhmad Hanafi Dain Yunta. "Mewujudkan Masyarakat Qur'ani melalui Program KKN STIBA Makassar di Desa Kalabbirang Kabupaten Maros." WAHATUL MUJTAMA': Jurnal Pengabdian Masyarakat 1.2 (2020): 157-173.

Munawara, Munawara, and Iskandar Iskandar. "Implementasi Pengabdian Masyarakat melalui Pelaksanaan Dirasah Islamiyah di Desa Tukamasea Kabupaten Maros." WAHATUL MUJTAMA': Jurnal Pengabdian Masyarakat 1.2 (2020): 174-184.

Potensi Daerah Bangka Belitung. https://bakuda.babelprov.go.id/content/potensidaerah-bangka-belitung

Putri, Sri Ujiana, and Aswar Aswar. "Implementasi Pendidikan Masyarakat Berbasis Masjid untuk Muslimah di Desa Mattoanging Kabupaten Maros." WAHATUL MUJTAMA': Jurnal Pengabdian Masyarakat 1.2 (2020): 129141.

Hijrayanti Sari, M. Amirullah, Aswar. Pengajian Virtual Muslimah... 
- Jurnal — WAHATUL MUJTAMA': Jurnal Pengabdian Masyarakat

WAHATUL Vol. 2, No. 1 (2021): Hal. 102-115

MUJTAMA'

JURNAL PENGABDIAN

Website: https://journal.stiba.ac.id

ISSN: 2723-6013 (Online)

Soyusiawaty, Dewi, Rusydi Umar, and Rochmat Mantofani. "Sistem Informasi

Geografis Objek Wisata Propinsi Kepulauan Bangka Belitung Berbasis

Web." Seminar Nasional Aplikasi Teknologi Informasi (SNATI). 2007.

Syahriani, Eka, and Awal Rifai. "Upaya Meningkatkan Pemahaman Keagamaan

Masyarakat melalui Program Pendidikan dan Sosial Keagamaan di Desa

Alatengae Kabupaten Maros." WAHATUL MUJTAMA': Jurnal

Pengabdian Masyarakat 1.2 (2020): 142-156.

Tempo, Rachmat Bin Badani, and Khaerul Aqbar. "Ikhtiar Mahasiswa KKN

STIBA Makassar dalam Pembentukan Akhlak Qur'ani Masyarakat Desa

Balassuka Kabupaten Gowa." WAHATUL MUJTAMA': Jurnal Pengabdian Masyarakat 1.1 (2020): 90-115.

Wardhani, Rulyanti Susi, and Devi Valeriani. "Green Tourism dalam Pengembangan Pariwisata Bangka Belitung." Prosiding Seminar Nasional INDOCOMPAC. 2016.

Wijaya, Hendra. "Pembelajaran Metode Dirosa di Desa Majannang Kabupaten Gowa." WAHATUL MUJTAMA': Jurnal Pengabdian Masyarakat 1.1 (2020): 67-74. 